\title{
Research on the Core of "Artisan Spirit" in Education
}

\author{
Libo Yang \\ Guangdong University of Science \& Technology, Dongguan, Guangdong, 523083
}

Keywords: "Artisan spirit"; core; practical; development

\begin{abstract}
There is a famous artisan in ancient China. It can be said that he is more than Edison. The originator of the civil engineering craftsman of our country, Luban, is an ordinary and extraordinary person. During his life, Lu Ban tirelessly strived for excellence and invented many tools ${ }^{[1]}$. The tools he invented had an important impact on the productivity of society at that time. In fact, the so-called "artisan spirit" is this kind of tireless spirit of work. To be precise, this is the work attitude and work style. The core of "artisan spirit", and the influence of this "artisan spirit" on our work and life are described in this paper to finally carry forward the "artisan spirit."
\end{abstract}

\section{Introduction}

The ancient saying goes: There is something difficult and easy to do in the world, and it is also difficult for those who are difficult. Now we, as a member of the electromechanical work, tirelessly strive for excellence is an important prerequisite for our good work. With such an attitude, no matter what kind of difficulties arise in the work, we can solve it and make the ordinary work better and better. In addition, is the core of "artisan spirit" only these? Or how do we practice this "artisan spirit" in our lives?

\section{Sources and Cores of "Artisan Spirit"}

\subsection{Sources of "Artisan Spirit"}

The term "artisan spirit" was first produced by Nie Shengzhe. The first class wood craftsmen he cultivated came from this spirit. Craftsmanship refers to the craftsman's meticulous craftsmanship of his own products, his quest for excellence, and his perfect spirit. Craftsmen like to constantly polish their own products, constantly improve their craft, and enjoy the process of product sublimation in their hands. The goal of the craftsmanship is to create the highest quality products in the industry and other products that cannot be matched by peers. To sum up, the craftsmanship spirit is the pursuit of excellence in the creation of spirit, the spirit of excellence in quality, customer-oriented service spirit.

The spirit of the craftsman is not an imported product. In "Zhuangzi", there is a story about "Buddha's solution to cattle." The chef gave Liang Hui Wang a slaughtered cow. Where his hands touched, where the shoulders depended on, where the feet were treading, where the top of the knees had creaked, when the knife came in, there was no discord. Liang Huiwang asked: "How could your technique of cattle solitude be superb to this extent?" The chef replied that he took the spirit and the cow's contact instead of his eyes, according to the original construction of the bovine body. Insert the gapped bone joint with a very thin blade. In nineteen years, his blade was as sharp as he had just grinded from the whetstone. The chef also said: Whenever he encounters cross-stitching where it is difficult to cut a knife, he carefully raises his attention. The vision is concentrated, the movement slows down, the knife moves very lightly, and the bone and flesh of the cow are heard. Suddenly it will be solved ${ }^{[2]}$.

The story of Peking's solution to the cows tells people a truth. To do anything to achieve the purpose and attainment of God, it is possible to reach the realm of culmination and exaltation. Take a look at Swiss watches and take a technology to the extreme. Top quality creates top brands. 


\subsection{The core of "Artisan Spirit "}

Craftsmanship is a product of the era of industrial economy. It is a demand for refined production. It is also applicable to agricultural production. In terms of agricultural production, food safety is actually guaranteed at the source. From the start of planting, raw materials, fertilizers, and land are required to ensure safety, as well as its quality and quality. The spirit of craftsmen is also needed here. Craftsmanship is to require the company to be like a craftsman, to ponder over its own products, strive for excellence, stand the test and scrutiny of the market. The core of craftsmanship is the pursuit of technological innovation and technological progress. If the enterprise is the lifeline of the country's economy, then an enterprise with technological innovation and technological progress as the main body is the driving force behind the nation's revitalization and the source of the nation's increased wealth.

All in all, I think there are three cores of "artisan spirit". They are fun and passionate, persistent, strong and patient. Being able to live with your heart, work hard, manage your heart, and interpret your life with your heart are the best interpretations of "artisan spirit" that each of us can do ${ }^{[3]}$.

So, what about the staff of our electromechanical industry? "Artisan spirit" is also applicable, and we must continue to pursue innovation and development in the course of our work. We must innovate our work while maintaining stability. Create a certain value for the company and the country. Here are some pictures showing the serious work of electromechanical workers. They are used to promote you and progress together.
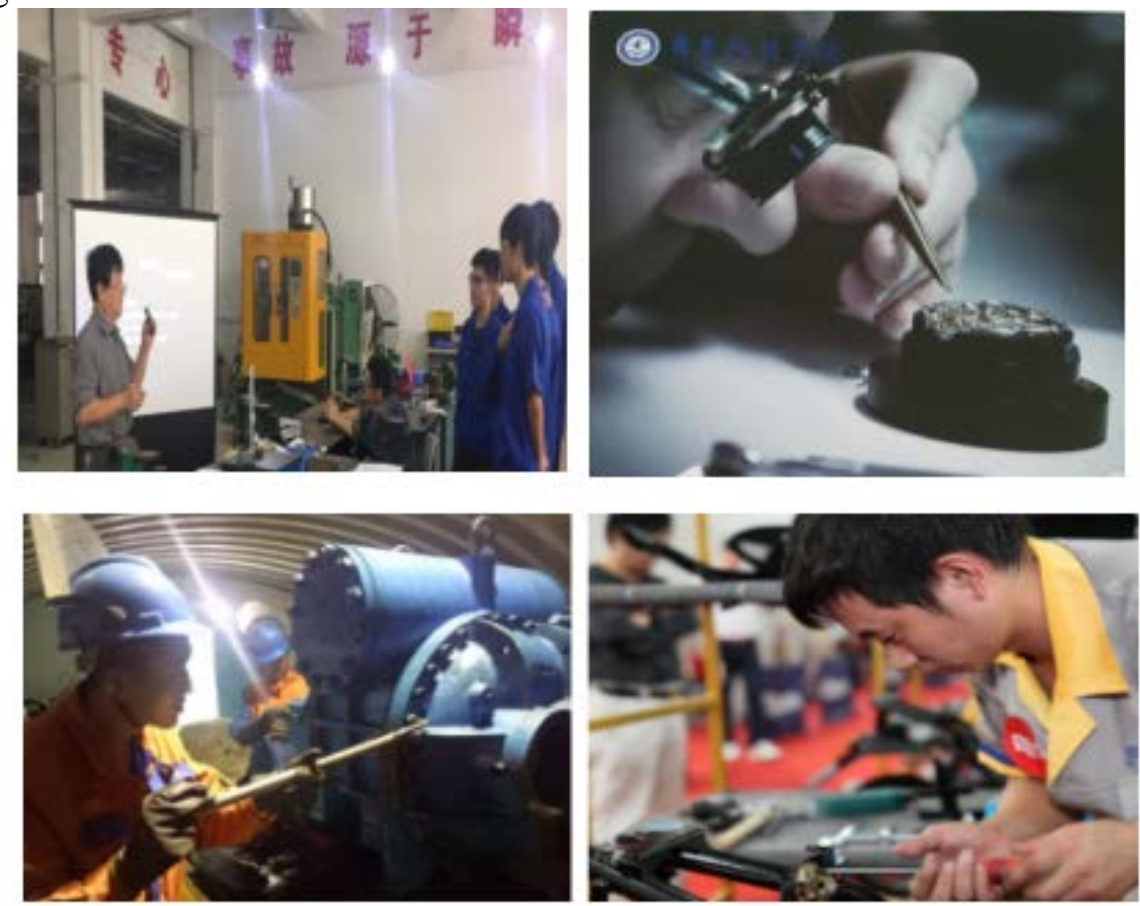

Fig. 1 Electromechanical worker display work

\section{The Influence of "Artisan spirit"}

In the first few years after the founding of the People's Republic, our country was once in a quandary, and the high import prices of oil added to our new country. At this time, in a place called Daqing, it was this person who People shouted: "We must also get a big oil field desperately." Since then, our country has obtained sufficient oil resources, freed itself from the fate of imported high-priced oil and embarked on the road of accelerating development. This is true of the country, and it is also true of individuals. Today, we seem to have escaped the difficult years. But this is not enough. Our work is no longer just for the sake of feeding. We have many pursuits. We must have that kind of pursuit. "Artisan spirit", because we tirelessly can get us out of difficulties, and excellence can satisfy our inner desire to pursue excellence. 
In recent years, many Chinese advanced figures such as Lu Ban and Wang Jinxi have emerged in the selection of moving Chinese characters and model evaluations. They used their actions to practice the spiritual instructions of the arduous struggles passed down by their ancestors and responded to the motherland with wisdom. And people's expectations ${ }^{[4]}$. Li Xueling, who was willing to exchange odours for 10,000 households, was not afraid of being dirty and not afraid of foul smells. He worked hard to create a good living and working environment for the public on the Beijing Sanitation Front. He deserved to be a vanguard model; Zhu Yuhua was willing to stay awake without delay. The customer's one-minute good conduct laid a solid foundation for her later career development. If we all can work tirelessly in the work, we can become a great person.

\section{Carry forward "Artisan Spirit"}

First, we must inherit the tradition and be willing to craft it. From slash and slash and burn to the present day, 5,000 years from the slash and slash cultivation of China, hard work and hard work are the valuable spiritual wealth left by our ancestors. As workers in the electromechanical industry, we must also think of how to improve work efficiency. How to better serve the people? It is our requirement to work tirelessly and tirelessly. Second, we must keep up with the times and innovate. Since the birth of human beings was more than 30 million years ago, if there is no innovation, I am afraid that we are still living in primitive times. As an electromechanical worker, working tirelessly is our working attitude, and blazing new trails is our pursuit of work. In today's rapidly developing society, if you want to not be eliminated by the society, you must promote "artisan spirit", do your own job, and do not forget to promote yourself so as not to be forgotten by the world and forgotten by your boss.

Second, electromechanical workers must contribute to "Made in China." The famous entrepreneur and educator Nie Shengzhe once called for: "Made in China" is the best gift given to China by the world. To cherish this opportunity for training, it must not be easily lost. "Made in China" makes perfect practice, you can transition to "Chinese precision". "China's fine manufacturing" is stable, and it is not afraid of not having "China created." Do not let "Made in China" die before it matures. The road must go one step at a time, and humanization (crafting) is the basis and prerequisite for automation. We must have artisan spirit from "craftsmanship" to "smith soul". First-rate craftsmen have to train from teenagers, and some industries even begin training from the age of 12 . To resume apprenticeship as soon as possible. To reform the tax system, it is necessary to promote the importance that local governments attach to manufacturing.

Third, sink in and improve quality. Today's society is overwhelming, and pursues the immediate benefits brought by "short, flat, fast" (less investment, short cycle, quick effect), thus ignoring the soul of the product. Therefore, enterprises need the craftsman spirit to succeed in the long-term competition. When other companies are keen on the cycle of "circling money, making a product to die, re-launching new products, and recirculating money", companies that adhere to the "artisan spirit" rely on their beliefs and beliefs to watch the product continuously improve and improve. After experiencing high standards and experience, it has become the pride of many users. Regardless of their success or failure, their spirit is complete and enjoyable. It is both refined and positive. There are many reasons why many companies in China have poor product quality ${ }^{[5]}$. But in the end, it can be attributed to one aspect, that is, lack of rigorous craftsmanship. One of the important reasons why China's products are of inferior quality to Japan is that people do things more rigorous than we do, and they also have the craftsman spirit. Businesses cannot blindly learn and introduce Japanese-style management. The most worthwhile learning of Japanese management is a spirit, not a specific practice. This spirit is the spirit of a craftsman. The so-called Craftsmanship is the first thing you love to do, and it is better than the money you bring to them. The second is excellence and meticulous craftsmanship. Lean management is the word "fine" and "benefit." In the Japanese concept, you increase it from $60 \%$ to $99 \%$, and from $99 \%$ to $99.99 \%$ is a concept. They do not compete with others and compete with one another.

In general, the promotion of the broad "artisan spirit" is conducive to our mechanical and electrical 
employees to do their own work, help us to elevate ourselves, and more conducive to shaping our dream of realizing the great rejuvenation of the Chinese nation.

\section{Conclusion}

Once a craftsman was an indispensable profession in the daily life of ordinary Chinese people. Carpenters, coppersmiths, blacksmiths, masons, enamelsmiths, etc., all kinds of craftsmen used their superb skills to set the background for traditional life. With the end of the farming era, society has entered the post-industrial era, and some old craftsmen and old craftsmen who are incompatible with modern life have gradually faded out of daily life. However, the craftsman spirit is never out of date.

\section{Acknowledgment}

This paper is funded by Project of: The value of craftsman spirit in the innovation and entrepreneurship of education in vocational college. Higher vocational and technical education research association of guangdong province in 2016 (GDGZ16Y142).

Research on the cultivation of "artisan spirit" in the practice teaching of mechanical electronic engineering, higher-education reform of Guangdong universities in 2016 (Higher Education Division of Guangdong Provincial Education Department No. 236 Document).

\section{References}

[1] Ye Xi, Liu Lin. A brief discussion on the cultivation of the spirit of contemporary craftsmen [J]. Vocational Education Forum, 2015, 34:80-85.

[2] Hu Bing, Li Xiaolu. Reflection on Cultivating Spirit of Artisan under the Defect of Rationality[J]. Higher Education Exploration, 2016,05:85-89.

[3] Liu Dongling. Casting "Artisan Spirit"[J]. VTC, 2016, 14:3.

[4] Yang Guitao. Exploration of the "Craftsman" spirit in the promotion of career literacy in higher vocational students [J]. Chinese Training, 2016, 12:15-16.

[5] Zhang Xugang. Discussion on "Artisan Spirit"[J]. Journal of Henan University of Technology (Social Sciences Edition),2016,03:171-176. 